\title{
Multiple Brain Abscesses Due to Nocardia otitidiscaviarum: Case Report and Treatment Implications
}

\author{
Evan H. Einstein ${ }^{1}$, David Bonda ${ }^{1}$, Salman Khan ${ }^{2}$, Avraham B. Zlochower ${ }^{3}$, Randy S. D'Amico ${ }^{1}$
}

1. Neurosurgery, Lenox Hill Hospital/Donald and Barbara Zucker School of Medicine at Hofstra, New York, USA 2. Infectious Disease, Lenox Hill Hospital/Donald and Barbara Zucker School of Medicine at Hofstra, New York, USA 3. Radiology, Lenox Hill Hospital/Donald and Barbara Zucker School of Medicine at Hofstra, New York, USA

Corresponding author: Evan H. Einstein, eveinstein@gmail.com

\begin{abstract}
Nocardia infections typically present in immunocompromised hosts. Brain abscesses caused by species such as Nocardia asteroides, farcinica, and abscessus are well-documented in the literature. We present a rare case of an immunocompetent patient with multiple brain abscesses due to Nocardia otitidiscaviarum requiring a decompressive fronto-temporoparietal craniectomy due to symptomatic intracranial hypertension. The patient was treated with intrathecal amikacin in addition to standard antibiotics with the resolution of the disease and good neurologic outcome. This is one of few case reports overall involving this species within the brain, and the second to report favorable outcomes. This case describes implications for treatment and adds to sparse literature regarding this particular pathogen.
\end{abstract}

Categories: Radiology, Infectious Disease, Neurosurgery

Keywords: nocardia, brain abscess, nocardia otitidiscaviarum, intrathecal antibiotics, decompressive hemicraniectomy

\section{Introduction}

Nocardia is a genus representing a ubiquitous group of aerobic, gram-positive bacteria typically causing opportunistic infections in immunocompromised hosts [1]. These infections typically occur in the pulmonary system, with the central nervous system (CNS) being the most common site of extrapulmonary nocardiosis [2]. Although nocardial brain abscesses often occur in immunocompromised patients [3-4], multiple case reports have demonstrated these abscesses in immunocompetent patients as well [5-10]. Nocardia otitidiscaviarum is a relatively rare species occurring in approximately $3 \%$ of overall general Nocardia cases [11], with only three published reports describing brain abscesses in immunocompetent hosts [12-14]. We present a case of an immunocompetent patient with multiple brain abscesses caused by Nocardia otitidiscaviarum. The patient was treated with decompressive craniectomy due to symptomatic intracranial hypertension and a combination of systemic and intrathecal antibiotic therapy with resolution of the disease and good neurologic outcome. This is the second report of a favorable outcome in an immunocompetent individual and describes an aggressive treatment strategy that may have implications on

Review began 03/10/2021 Review ended 04/05/2021 Published 04/08/2021

\section{(c) Copyright 2021}

Einstein et al. This is an open access article distributed under the terms of the Creative Commons Attribution License CC-BY 4.0., which permits unrestricted use, distribution, and reproduction in any medium, provided the original author and source are credited. future therapy for this rare disease.

\section{Case Presentation}

A 46-year-old man with a history of controlled type 2 diabetes (A1C 6.8 percent on admission), employed as a landscaper, presented to an outside hospital with intermittent fevers, chills, weight loss, and generalized weakness. He was found to have bilateral pneumonia and underwent a bronchoscopy yielding biopsies with negative cultures, negative fungal and acid-fast bacilli (AFB) stains, and pathology consistent with inflammation. He was treated with a course of amoxicillin-clavulanate and discharged with a plan to follow up with outpatient pulmonology given the ongoing uncertainty of his pulmonary diagnosis.

He presented to our institution two weeks later after a new-onset generalized tonic-clonic seizure. The patient had been experiencing a frontal headache with increasing aggression and confusion the day prior to presentation. Upon arrival, the patient was afebrile and hemodynamically stable. Laboratory values demonstrated a white blood cell (WBC) count of $8.45 \times 10^{9}$ cells/L, red blood cell (RBC) count of $3.78 \times$ $10^{12}$ cells/L, platelets of $144 \times 10^{9}$ cells/L, absolute cluster of differentiation 3 (CD3) count of 612 cells $/ \mu \mathrm{L}$, and absolute CD4 count of 239 cells/ $\mu \mathrm{L}$. He was human immunodeficiency virus (HIV) negative. His neurologic exam demonstrated an altered sensorium, as he was only oriented to self and intermittently attentive to the interview. He otherwise did not demonstrate any focal neurologic deficits and all cranial nerves appeared to be intact.

The patient was started on levetiracetam for seizure prophylaxis, as well as intravenously (IV) administered acyclovir, ceftriaxone, vancomycin, and dexamethasone for suspected meningoencephalitis. Blood cultures 


\section{Cureus}

were negative. CT chest demonstrated reticulonodular opacities and mediastinal lymphadenopathy (Figure 1). CT abdomen demonstrated hepatosplenomegaly. MRI brain with contrast demonstrated numerous, multifocal, ring-enhancing fluid collections throughout bilateral cerebral and cerebellar hemispheres with associated restricted diffusion on diffusion-weighted imaging (Figure 2). These were interpreted as multiple abscesses within the frontal, parietal, temporal, and occipital lobes and cerebellum bilaterally.
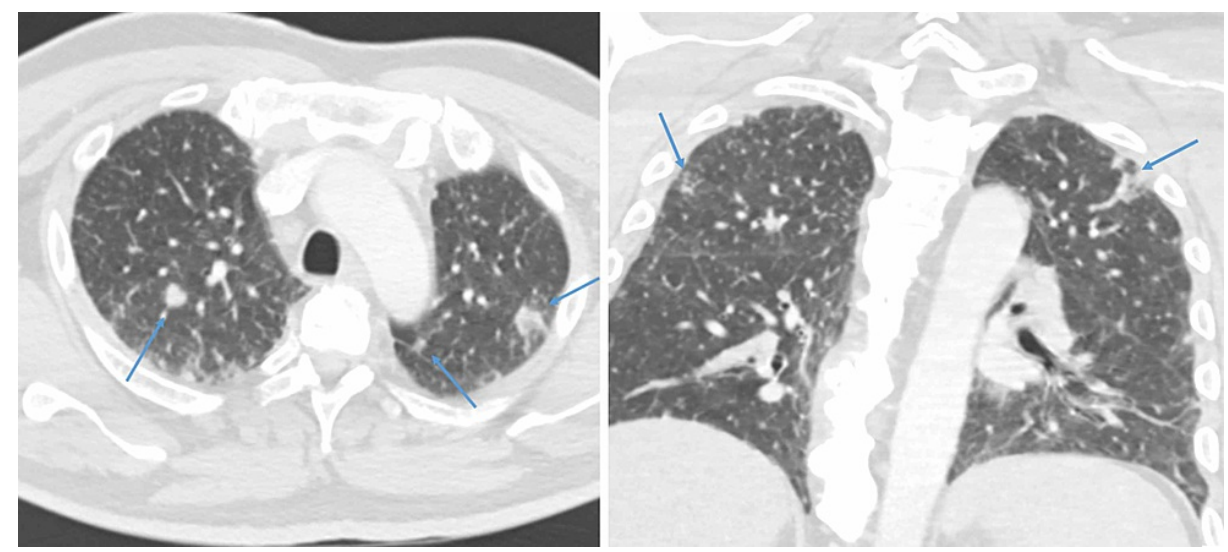

FIGURE 1: Axial and coronal CT chest images demonstrating numerous pulmonary nodules 


\section{Cureus}
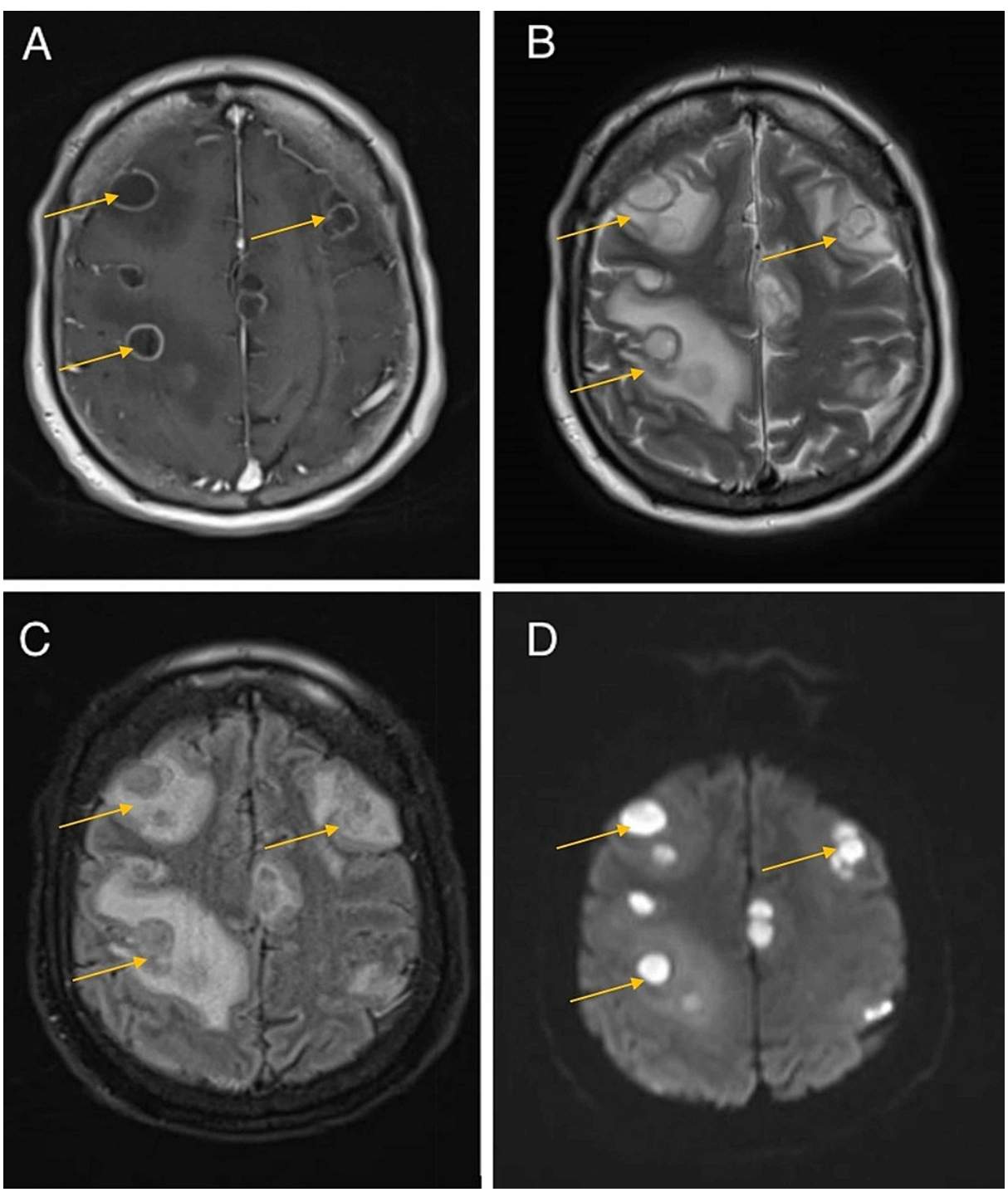

\section{FIGURE 2: Initial MR brain imaging of the patient following new-onset}

tonic-clonic seizure

(A) T1-weighted post-contrast imaging demonstrating multiple ring-enhancing lesions. (B) T2-weighted image demonstrating multiple hyperintense lesions with surrounding hyperintensity due to vasogenic edema. (C) T2-weighted-fluid-attenuated inversion recovery (T2-FLAIR) image demonstrating isointense signal within the lesions with surrounding hyperintensity due to vasogenic edema. (D) Diffusion-weighted imaging (DWI) restricted diffusion within the lesions consistent with an abscess.

Given the uncertainty of the diagnosis and newly identified symptomatic cerebral abscesses, the patient initially underwent a right frontal craniotomy with biopsy and aspiration of a lesion and a lumbar puncture. Cerebrospinal fluid (CSF) studies demonstrated 84\% neutrophils, 14\% lymphocytes, $2 \%$ monocytes, protein of $85 \mathrm{mg} / \mathrm{dL}$, and glucose of $46 \mathrm{mg} / \mathrm{dL}$. Initial aspirates grew Nocardia otitidiscaviarum (identified via matrixassisted laser desorption ionization-time of flight mass spectrometry (MALDI-TOF MS)); the isolate was sent for antimicrobial susceptibility testing. Gomori methenamine silver (GMS) stain showed beaded branching filaments in brain tissue, consistent with invasive CNS nocardiosis (Figure 3). Antimicrobial agents were initially broadened to include coverage with imipenem and linezolid and adjusted to include IV amikacin (1200 mg/day), imipenem (three g/day), and trimethoprim/sulfamethoxazole (TMP/SMX; 15 $\mathrm{mg} / \mathrm{kg} /$ day of the trimethoprim component). Cultures eventually speciated with Nocardia otitidiscaviarum, demonstrating susceptibilities to TMP/SMX, amikacin, tobramycin, and minocycline. As a result, linezolid was discontinued and minocycline $(200 \mathrm{mg} /$ day) was initiated. 


\section{Cureus}

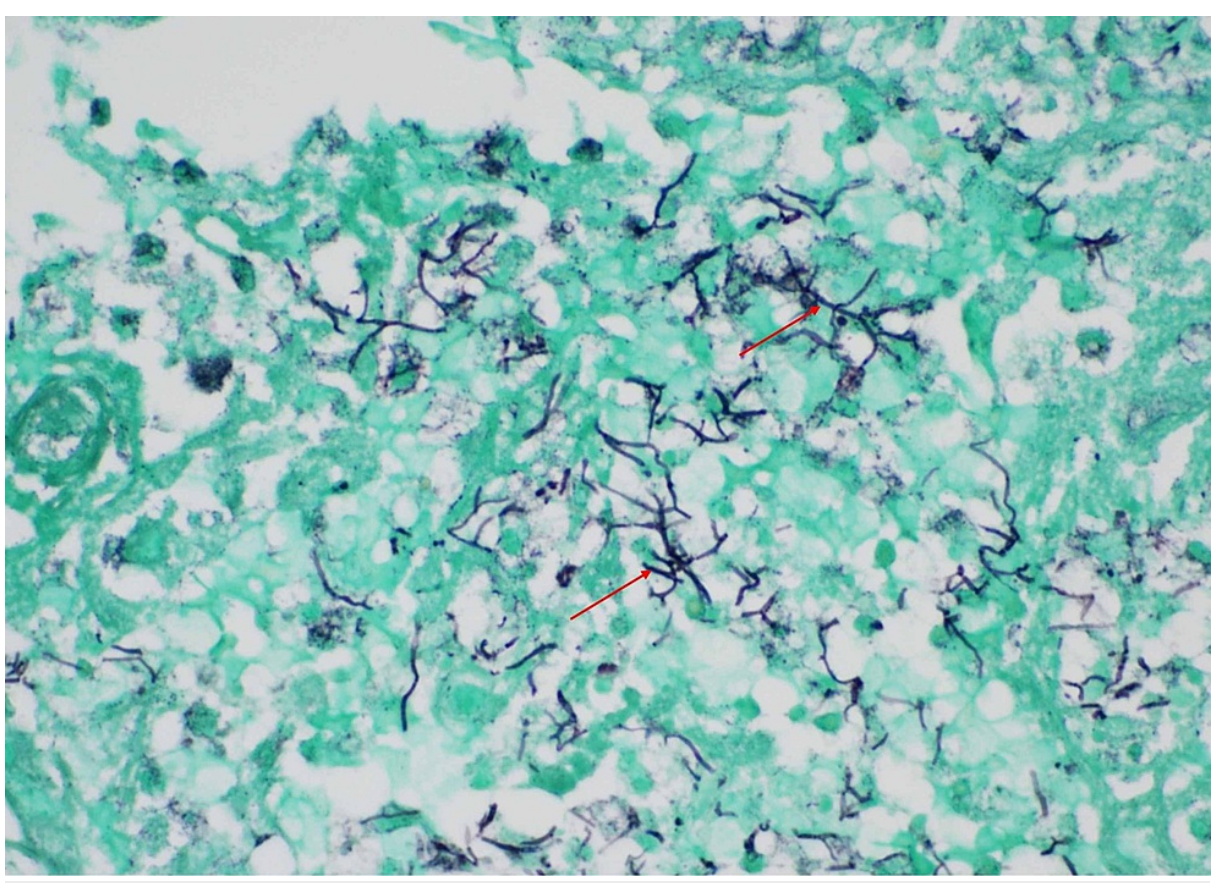

FIGURE 3: GMS stain taken at $600 x$ magnification showing thin septate fungal hyphae, consistent with Nocardia spp

Gomori methenamine silver (GMS) stain photomicrograph taken at $600 x$, demonstrating thin septate fungal hyphae, consistent with Nocardia spp.

Approximately five days following the initiation of this treatment regimen, the patient's mental status deteriorated. The patient became obtunded, not following commands, not moving all four extremities, and ultimately required intubation for airway protection. His neurologic examination further revealed anisocoria with a left nonreactive pupil, with cough and gag reflexes intact. CT scan of the head demonstrated enlargement of the multiple bilateral lesions with significant surrounding edema and mass effect worse on the right than the left (Figure 4). The patient was taken for a decompressive right hemicraniectomy with the placement of a right frontal external ventricular drain (EVD) for consideration of intrathecal therapy. In addition, aspiration of a larger abscess located in the right frontal lobe was performed. 


\section{Cureus}
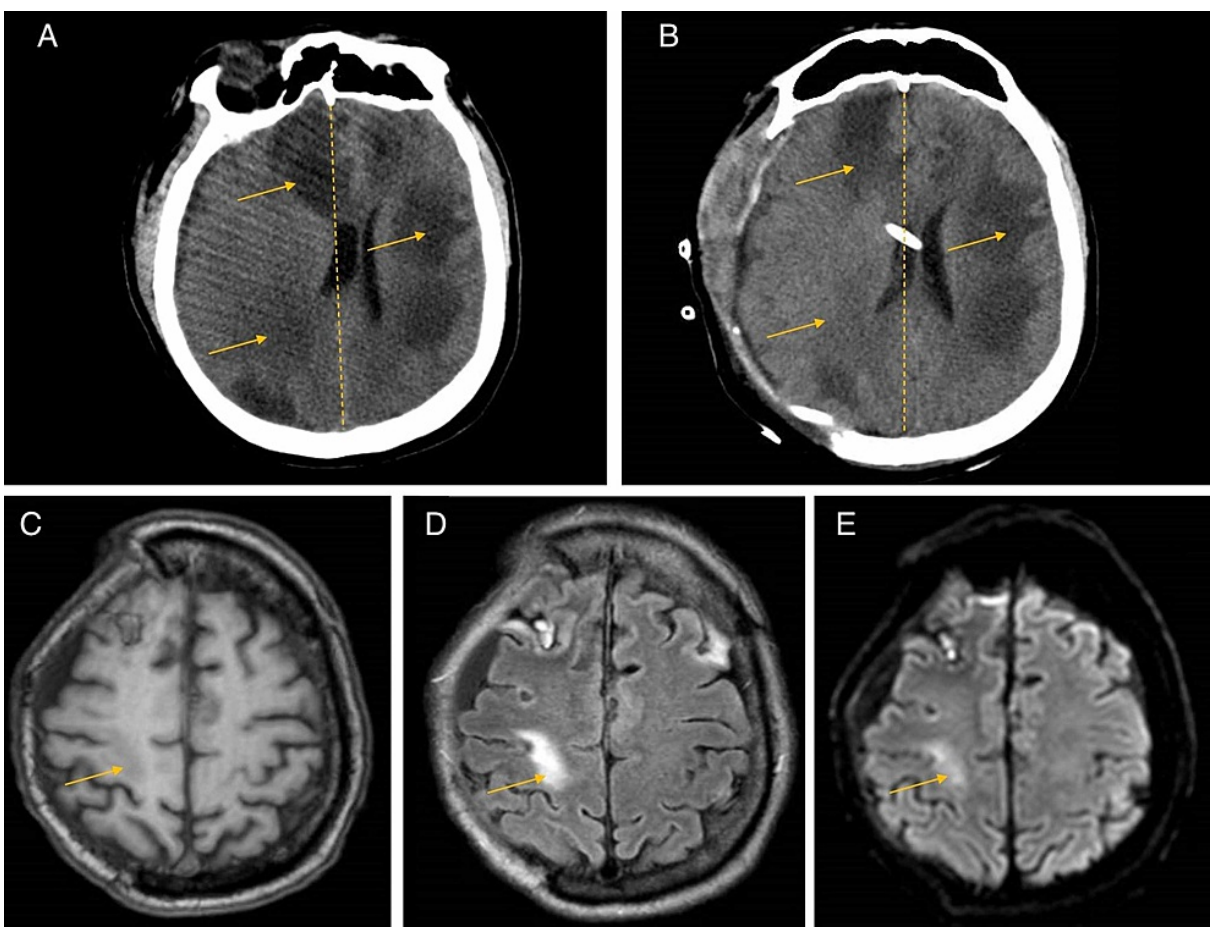

\section{FIGURE 4: Peri-operative CT brain imaging and three-month postoperative MR brain imaging}

(A) Pre-operative CT head image demonstrating mass effect and midline shift more significant on the right side. (B) Postoperative CT head image after right decompressive hemicraniectomy. (C) Three-month postoperative T1-weighted post-contrast MR image demonstrating marked improvement of lesions. (D) Three-month postoperative T2-weighted-fluid-attenuated inversion recovery (T2-FLAIR) image further demonstrating an improvement of multifocal sites of confluent white matter, with the continuing resolution of vasogenic edema. $(E)$ Three-month postoperative diffusion-weighted imaging (DWI) MR image demonstrating resolution of disease.

In the setting of continued fluctuations in mental status as well as low EVD output, a trial of intrathecal amikacin was initiated. The patient received two total doses of $30 \mathrm{mg}$ approximately 72 hours apart. Repeat CSF studies demonstrated no white blood cells, protein of less than $4 \mathrm{mg} / \mathrm{dL}$, and glucose of $3 \mathrm{mg} / \mathrm{dL}$. Intrathecal antibiotics were then discontinued, and the EVD was pulled. The patient's mental status gradually improved. He completed a six-week course of combination therapy with IV amikacin, TMP/SMX, and minocycline and was then transitioned to dual therapy with oral TMP/SMX plus minocycline with a plan to continue for one year; following this, he will be transitioned to lifelong secondary prophylaxis with TMP/SMX. Follow-up MR imaging was done at one month and three months, demonstrating resolution of abscesses (Figure 4). A cranioplasty was completed approximately three months following the hemicraniectomy. Neurologic examination postoperatively was within normal limits overall aside from a moderate decrease in strength in his left upper extremity and proximal lower extremity. He was otherwise fully alert, oriented, without dysarthria or other focal deficits. He was ultimately discharged home for routine follow-up and physical therapy.

\section{Discussion}

Nocardia is a genus representing a ubiquitous group of bacteria usually found in soil, organic matter, freshwater, and saltwater [1]. Nocardia otitidiscaviarum was first isolated from a guinea pig with ear disease in 1924 and has since been known as a rare opportunistic pathogen that causes primary cutaneous, lymphocutaneous, and pulmonary infections in immunocompromised patients as well as immunocompetent patients [11]. There were no published case reports of Nocardia otitidiscaviarum infection in humans until the mid-1960s, and it has been estimated that approximately $3 \%$ of Nocardia infections are due to this species.

The case in this report describes a rare presentation of multiple brain abscesses formed due to Nocardia otitidiscaviarum infection in an immunocompetent patient. Although several case reports of nocardial brain abscesses in immunocompetent hosts exist in the literature, these cases are due to Nocardia species that are more common such as Nocardia abscessus [5-6], Nocardia farcinica [7-8], and Nocardia asteroides [9-10]. Most of these cases involved a single abscess for which a craniotomy and aspiration were performed before a prolonged course of antibiotics. These immunocompetent patients improved significantly following treatment, with a resolution of neurologic symptoms and no recurrence of the disease. 
Although a majority of extrapulmonary cases of nocardiosis occur in the CNS [2], there are only three reported cases of Nocardia otitidiscaviarum brain abscesses in immunocompetent hosts [12-14]. These relatively recent cases are outlined in Table 1 , as is the case presented in this report. The cases in the literature involved varying antimicrobial regimens based on sensitivities, as well as varying surgical interventions, with only two cases to date reporting patient survival after prolonged hospital courses. One case involved a patient who died before surgical intervention [14]. Two other older case reports [15-16] also described patients with Nocardia otitidiscaviarum brain abscess who died as well. The primary neurosurgical intervention used in this case and most other cases [12-13], at least initially, was craniotomy with drainage of abscesses. This is standard also for the identification of the causative pathogen [17]. The case described in this report is the first case of Nocardia otitidiscaviarum brain abscess that necessitated hemicraniectomy. Although intrathecal antimicrobial agents have been delivered in other cases of brain abscess [17], this report also describes the first case where this technique was used for Nocardia otitidiscaviarum brain abscess specifically, with eventual resolution of disease. Although the course of intrathecal amikacin presented here was short, it is possible that direct intrathecal delivery of antibiotics expedited the treatment and resolution of intracranial disease.

\begin{tabular}{|c|c|c|c|c|c|c|}
\hline Case & Presentation & $\begin{array}{l}\text { Past Medical } \\
\text { History }\end{array}$ & Extent of Disease & Medical Management & $\begin{array}{l}\text { Surgical } \\
\text { Management }\end{array}$ & Outcome \\
\hline $\begin{array}{l}\text { Eren et } \\
\text { al. } \\
(2016) \\
{[12]}\end{array}$ & $\begin{array}{l}\text { A } 69 \text {-year- } \\
\text { old woman } \\
\text { with } 10 \text { days } \\
\text { of mild right } \\
\text { hemiparesis. }\end{array}$ & None & $\begin{array}{l}\text { Multiple bilateral } \\
\text { hemispheric lesions on } \\
\text { MRI. }\end{array}$ & $\begin{array}{l}\text { Initially meropenem ( } 6 \mathrm{~g} / \text { day) and amikacin ( } 1 \mathrm{~g} / \text { day), } \\
\text { then switched to meropenem ( } 6 \mathrm{~g} / \text { day) and } \\
\text { TMP/SMX ( } 3600 \mathrm{mg} / \mathrm{day}) \text {. After eight weeks of IV } \\
\text { antimicrobial therapy, the patient was discharged on } \\
\text { oral TMP/SMX. }\end{array}$ & $\begin{array}{l}\text { Lesions were } \\
\text { drained by } \\
\text { stereotactic } \\
\text { craniotomy once } \\
\text { a week } \\
\text { consecutively for } \\
\text { three weeks. }\end{array}$ & $\begin{array}{l}\text { Regression } \\
\text { of lesions } \\
\text { confirmed at } \\
\text { 1-year MRI. }\end{array}$ \\
\hline $\begin{array}{l}\text { Ishihara } \\
\text { et al. } \\
\text { (2014) } \\
{[13]}\end{array}$ & $\begin{array}{l}\text { A 79-year- } \\
\text { old woman } \\
\text { with five } \\
\text { days of mild } \\
\text { left } \\
\text { hemiparesis } \\
\text { and } \\
\text { progressive } \\
\text { amnesia. }\end{array}$ & $\begin{array}{l}\text { History of } \\
\text { tuberculosis } \\
\text { in her 20s. }\end{array}$ & $\begin{array}{l}\text { A single ring-enhancing } \\
\text { lesion in the right frontal } \\
\text { lobe with surrounding } \\
\text { edema on MRI. }\end{array}$ & $\begin{array}{l}\text { Initially managed with meropenem ( } 6 \mathrm{~g} / \text { day), } \\
\text { sulbactam/ampicillin ( } 3 \text { g/day), and cefozopran ( } 2 \\
\mathrm{~g} / \text { day) before surgical intervention. After the second } \\
\text { abscess drainage, the patient was switched to oral } \\
\text { TMP/SMX. }\end{array}$ & $\begin{array}{l}\text { The lesion was } \\
\text { aspirated twice } \\
\text { via craniotomy. }\end{array}$ & $\begin{array}{l}\text { Resolution } \\
\text { of lesion } \\
\text { though with } \\
\text { persisting } \\
\text { anosognosia } \\
\text { and } \\
\text { unilateral } \\
\text { spatial } \\
\text { neglect. }\end{array}$ \\
\hline $\begin{array}{l}\text { Pelaez } \\
\text { et al. } \\
(2009) \\
{[14]}\end{array}$ & $\begin{array}{l}\text { An 85-year- } \\
\text { old woman } \\
\text { who was } \\
\text { initially } \\
\text { admitted for } \\
\text { dyspnea, } \\
\text { cough, and } \\
\text { pleuritic } \\
\text { chest pain. }\end{array}$ & $\begin{array}{l}\text { History of } \\
\text { chronic } \\
\text { obstructive } \\
\text { pulmonary } \\
\text { disease } \\
\text { (COPD), } \\
\text { coronary } \\
\text { artery } \\
\text { disease, and } \\
\text { hypertension. }\end{array}$ & $\begin{array}{l}\text { CT of the chest } \\
\text { demonstrated multiple } \\
\text { pulmonary nodules, and } \\
\text { CT of the brain } \\
\text { demonstrated a nodular } \\
\text { lesion in the left } \\
\text { frontotemporal lobe. }\end{array}$ & $\begin{array}{l}\text { Initial management involved IV TMP/SMX ( } 2400 / 480 \\
\mathrm{mg} / \text { day), and imipenem ( } 4 \mathrm{~g} / \text { day), which was then } \\
\text { switched to linezolid ( } 600 \mathrm{mg} \text { twice/day) and } \\
\text { dexamethasone }(40 \mathrm{mg} / \text { day). }\end{array}$ & $\begin{array}{l}\text { The patient died } \\
\text { before surgical } \\
\text { intervention. }\end{array}$ & $\begin{array}{l}\text { The patient } \\
\text { died. }\end{array}$ \\
\hline $\begin{array}{l}\text { Einstein } \\
\text { et al. } \\
(2020)\end{array}$ & $\begin{array}{l}\text { A 46-year- } \\
\text { old man } \\
\text { admitted for } \\
\text { new-onset } \\
\text { generalized } \\
\text { tonic-clonic } \\
\text { seizure and } \\
\text { altered } \\
\text { mental } \\
\text { status. }\end{array}$ & $\begin{array}{l}\text { History of } \\
\text { well- } \\
\text { controlled } \\
\text { type } 2 \\
\text { diabetes. }\end{array}$ & $\begin{array}{l}\text { CT chest demonstrated } \\
\text { multiple reticulonodular } \\
\text { opacities and mediastinal } \\
\text { lymphadenopathy. MRI } \\
\text { brain demonstrated } \\
\text { numerous ring-enhancing } \\
\text { lesions in bilateral } \\
\text { cerebral and cerebellar } \\
\text { hemispheres. }\end{array}$ & $\begin{array}{l}\text { Initial management involved Linezolid (1200 mg/day), } \\
\text { TMP/SMX (900 mg/day), imipenem, and amikacin } \\
\text { (1200 mg/day). After susceptibilities were obtained, } \\
\text { minocycline ( } 200 \mathrm{mg} / \text { day) was started, and imipenem } \\
\text { was discontinued. The patient also received two total } \\
\text { doses of } 30 \mathrm{mg} \text { amikacin intrathecally. Six weeks of } \\
\text { IV antibiotics treatment was followed by } 1 \text { year of } \\
\text { oral treatment with minocycline and TMP/SMX. }\end{array}$ & $\begin{array}{l}\text { Initial } \\
\text { management } \\
\text { involved } \\
\text { craniotomy and } \\
\text { biopsy, followed } \\
\text { by right } \\
\text { hemicraniectomy } \\
\text { and EVD } \\
\text { placement. }\end{array}$ & $\begin{array}{l}\text { Regression } \\
\text { of lesions } \\
\text { and } \\
\text { resolution of } \\
\text { altered } \\
\text { mental } \\
\text { status. }\end{array}$ \\
\hline & & tho & ; IV: intravenous; EI & ternal ventricular drain & & \\
\hline
\end{tabular}


susceptibilities (Table 1). Nocardia otitidiscaviarum is typically susceptible to kanamycin, gentamicin, amikacin, sulfamethoxazole, and ciprofloxacin [11]. It is generally resistant to ceftriaxone, ampicillin, amoxicillin-clavulanate, carbenicillin, and imipenem; it is often resistant to all beta-lactam antibiotics [11]. In the case described in this report, the species was susceptible to TMP/SMX, linezolid, amikacin, tobramycin, and minocycline, with resistance to imipenem, amoxicillin-clavulanate, ceftriaxone, ciprofloxacin, moxifloxacin, and clarithromycin. This led to a final regimen of amikacin, TMP/SMX, and minocycline.

Nocardiosis can be challenging to definitively diagnose, but it should be considered in a differential diagnosis in the setting of multiorgan disease especially involving the lungs and CNS. Broad-spectrum coverage should include an aminoglycoside such as amikacin, as well as TMP/SMX. Intrathecal amikacin could also be considered, as it was effective in our case as described.

\section{Conclusions}

In conclusion, Nocardia otitidiscaviarum brain abscess is a rare disease that has led to several fatalities. In standard fashion, a combination of IV antimicrobial agents and craniotomy with aspiration can be used as treatment. However, to prevent further neurologic decompensation and demise, it may be necessary to perform hemicraniectomy, as in our case. There may also be a role for intrathecal antibiotic therapy, potentially with amikacin as a primary agent. More cases will be needed to develop a more protocolized treatment for this specific disease. However, rapid identification of the pathogen, use of broad-spectrum antibiotics initially, understanding of antimicrobial susceptibilities, and timely neurosurgical intervention are clearly critical in ensuring the best possible patient outcome.

\section{Additional Information \\ Disclosures}

Human subjects: Consent was obtained or waived by all participants in this study. Conflicts of interest: In compliance with the ICMJE uniform disclosure form, all authors declare the following: Payment/services info: All authors have declared that no financial support was received from any organization for the submitted work. Financial relationships: All authors have declared that they have no financial relationships at present or within the previous three years with any organizations that might have an interest in the submitted work. Other relationships: All authors have declared that there are no other relationships or activities that could appear to have influenced the submitted work.

\section{Acknowledgements}

We would like to thank Dr. Samuel Wahl of Lenox Hill Hospital, Department of Pathology, for obtaining and providing us with the photomicrograph shown in Figure 3.

\section{References}

1. Wilson JW: Nocardiosis: updates and clinical overview . Mayo Clin Proc. 2012, 87:403-7. 10.1016/j.mayocp.2011.11.016

2. Beaman BL, Beaman L: Nocardia species: host-parasite relationships. Clin Microbiol Rev. 1994, 7:213-64. 10.1128/cmr.7.2.213

3. Lin YJ, Yang KY, Ho JT, Lee TC, Wang HC, Su FW: Nocardial brain abscess. J Clin Neurosci. 2010, 17:250-3. 10.1016/j.jocn.2009.01.032

4. Jeong JH, Moon SM, Park PW, et al.: Multiple brain abscesses caused by Nocardia asiatica in a patient with systemic lupus erythematosus: the first case report and literature review. Ann Lab Med. 2017, 37:459-461. 10.3343/alm.2017.37.5.459

5. Farran Y, Antony S: Nocardia abscessus-related intracranial aneurysm of the internal carotid artery with associated brain abscess: a case report and review of the literature. J Infect Public Health. 2016, 9:358-61. 10.1016/j.jiph.2015.11.009

6. Al Tawfiq JA, Mayman T, Memish ZA: Nocardia abscessus brain abscess in an immunocompetent host . I Infect Public Health. 2013, 6:158-61. 10.1016/j.jiph.2012.11.012

7. Iannotti CA, Hall GS, Procop GW, Tuohy MJ, Staugaitis SM, Weil RJ: Solitary Nocardia farcinica brain abscess in an immunocompetent adult mimicking metastatic brain tumor: rapid diagnosis by pyrosequencing and successful treatment. Surg Neurol. 2009, 72:74-9. 10.1016/j.surneu.2008.02.025

8. Kim S, Lee KL, Lee DM, et al.: Nocardia brain abscess in an immunocompetent patient . Infect Chemother. 2014, 46:45-9. 10.3947/ic.2014.46.1.45

9. Zhang Y, Zhu W, Ii Q, Hou B, Jia Y, Wei N, Pan Y: Nocardial brain abscess in an immunocompetent patient and review of literature. Chin Neurosurg J. 2016, 2:26. 10.1186/s41016-016-0043-6

10. Fleetwood IG, Embil JM, Ross IB: Nocardia asteroids cerebral abscess in immunocompetent hosts: report of three cases and review of surgical recommendations. Surg Neurol. 2000, 53:605-610. 10.1016/s00903019(00)00242-1

11. Brown-Elliott BA, Brown JM, Conville PS, Wallace RJ Jr: Clinical and laboratory features of the Nocardia spp. based on current molecular taxonomy. Clin Microbiol Rev. 2006, 19:259-82. 10.1128/CMR.19.2.259. 282.2006

12. Eren S, Ulu-Kilic A, Atalay A, Demiraslan H, Parkan O, Koc N: Report of an immunocompetent case with disseminated infection due to Nocardia otitidiscaviarum: Identification by $16 \mathrm{~S}$ rRNA gene sequencing. Infez 


\section{Cureus}

Med. 2016, 1:71-76.

13. Ishihara M, Takada D, Sugimoto K, Oguro H, Gonoi T, Akiyama Y, Yamaguchi S: Primary brain abscess caused by Nocardia otitidiscaviarum. Intern Med. 2014, 53:2007-12. 10.2169/internalmedicine.53.1450

14. Pelaez AI, Garcia-Suarez M, Manteca A, et al.: A fatal case of Nocardia otitidiscaviarum pulmonary infection and brain abscess: taxonomic characterization by molecular techniques. Ann Clin Microbiol Antimicrob. 2009, 8:11. 10.1186/1476-0711-8-11

15. Bradsher RW, Monson TP, Steele RW: Brain abscess due to Nocardia caviae: report of a fatal outcome associated with abnormal phagocyte function. Am J Clin Pathol. 1982, 78:124-7. 10.1093/ajcp/78.1.124

16. Talwar P, Chakrabarti A, Ayyagari A, Nayak N, Khosla VK, Minz M, Yadav RV: Brain abscess due to Nocardia. Mycopathologia. 1989, 108:21-3. 10.1007/BF00436779

17. Brouwer MC, Tunkel AR, McKhann GM 2nd, van de Beek D: Brain abscess. N Engl J Med. 2014, 371:447-56. 10.1056/NEJMra1301635 